\title{
The Urease Activity of Acinetobacter lwoffii and $A$. anitratus
}

\author{
By A. HENDERSON \\ Research Department, Glasgow Royal Maternity Hospital, \\ Rottenrow, Glasgow, Scotland
} (Accepted for publication 17 October 1966)

\begin{abstract}
SUMMARY
The production of urease by Acinetobacter lwoffii and $A$. anitratus was studied in 20 strains. It is concluded that both species may produce urease under appropriate conditions and that this property is of no value in differentiating between them. This conclusion was tested in 40 other strains of which 37 produced urease independently of saccharolytic activity.
\end{abstract}

\section{INTRODUCTION}

Many strains of Acinetobacter lwoffii and A. anitratus have now been studied by numerous workers; the reports reveal diversity of opinion about the presence of urease activity. A list of the reports and techniques used is given in Table 1 . The present study was undertaken on three grounds: (1) The diversity of results recorded in Table 1. (2) A strain of $A$. anitratus (reported by Lemoigne, Girard \& Jacobelli, 1952, as Neisseria winogradskyi and stated by these workers to be vigorous urease producers) did not give the urease reaction on Christensen medium (Christensen, 1946) when tested by the present author. (3) Jeffries (1964) suggested that certain strains of A. anitratus might fail to show urease activity when grown on ordinary test media, but that these strains might contain intracellular urease revealed only after ultrasonic disruption of the organism.

Table 1. Urease activity of Acinetobacter lwoffii and A. antitratus according to various investigators

\begin{tabular}{lcccl} 
Investigators & Date & $\begin{array}{c}\text { No. of } \\
\text { strains } \\
\text { tested }\end{array}$ & $\begin{array}{c}\text { No. of } \\
\text { strains } \\
\text { found to } \\
\text { produce } \\
\text { urease }\end{array}$ & \multicolumn{1}{c}{ Technique } \\
Hauber & 1948 & 15 & 15 & Christensen (1946) \\
\& Roberts & 1949 & 55 & 0 & Rustigian \& Stuart (1941) \\
& 1950 & 109 & 0 & Rustigian \& Stuart (1941) \\
\& Ral \& McGann & 1951 & 86 & 29 & Not stated \\
Mirard \& Jacobelli & 1952 & 18 & 18 & Modification of Grelet (1946) \\
& 1965 & 60 & 10 & Christensen (1946)
\end{tabular}

The present investigation falls into four parts: (1) The testing of strains of Acinetobacter anitratus and $A$. lwoffii on a variety of media containing urea. (2) The estimation of urea consumption when the bacteria were grown in urea + peptone 
water. (3) The estimation of urea consumption when the supernatant fluid of centrifuged disrupted bacteria was suspended in an aqueous solution of urea. (4) The estimation of ammonia produced during the growth of the bacteria in aqueous solutions of urea.

\section{METHODS}

Organisms. Most strains were obtained from culture collections with the addition of a few wild strains (see Table 2).

\section{Identity of organisms}

The organisms were required to conform to the description of Henderson (1965), namely: coccobacilli; catalase produced; indole and acetoin not produced; no acid from carbohydrates, when tested against $1 \%(\mathrm{w} / \mathrm{v})$ solutions of carbohydrate in peptone water, or, only from pentoses and hexoses, never dissacharides, trisaccharides, polysaccharides or alcohols, and the acid should be produced oxidatively and never fermentatively; ammonia always produced from peptone water; presence or absence

Table 2. Cultures of Acinetobacter

\begin{tabular}{|c|c|}
\hline A. lwoffii (Mima polymorpha) & *ACTC 9957 \\
\hline A. lwoffii (Moraxella lwoffii) & Inst. Pasteur, 5382 \\
\hline A. lwoffii (Moraxella lwoffii) & Inst. Pasteur, 53116 \\
\hline A. lwoffii & Wild strain A \\
\hline A. lwoffii & Wild strain $B$ \\
\hline A. lwoffii var. oxydans & Wild strain $\mathrm{C}$ \\
\hline A. lwoffii var. oxydans & Wild strain $\mathrm{D}$ \\
\hline A. Iwoffii var. oxydans & Wild strain $\mathrm{E}$ \\
\hline A. anitratus (в $5 \mathrm{w})$ & †NCTC 10292 \\
\hline A. anitratus & NCTC 7250 \\
\hline A. anitratus & NCTC 7412 \\
\hline A. anitratus & NCTC 7461 \\
\hline A. anitratus & NCTC 7844 \\
\hline A. anitratus & NCTC 9427 \\
\hline A. anitratus (Moraxella glucidolytica) & Inst. Pasteur, 5497 \\
\hline \multicolumn{2}{|l|}{ A. anitratus (Neisseria winogradskyi) } \\
\hline A. anitratus & Wild strain $\mathrm{F}$ \\
\hline A. anitratus & Wild strain G \\
\hline A. anitratus & Wild strain $\mathrm{H}$ \\
\hline A. anitratus & Wild strain I \\
\hline
\end{tabular}

of oxidase unimportant; nitrate not reduced to nitrite in broth. Jyssum \& Joner $(1965 a, b)$ have shown that these bacteria in fact utilize nitrite or nitrate as sole source of nitrogen and that repression of the nitrate-reducing system is caused by aspartic acid, alanine and amino acids biosynthetically related to them, though not by the ammonium ion. On the other hand, the activity of the nitrate-reducing system is inhibited by the ammonium ion, and ammonia is produced from the peptone which is the usual base of nitrate broths. The organisms are also known to convert nitrate to nitrite when grown in a succinate + nitrate medium but not in the presence of ammonia (personal communication from Dr C. A. Fewson, Department of Biochemistry, University of Glasgow). 


\section{PHYSIOLOGICAL TESTS}

All tests were made after incubation for 7 days at $37^{\circ}$.

Indole production was tested in peptone water with the reagent of Ehrlich (Cowan \& Steel, 1965).

Catalase was detected by effervescence on adding ' 10 vol.' hydrogen peroxide to peptone water cultures.

Acetoin was tested for by the method of Barrit (1936) in the simple medium recommended by the Ministry of Health (1934).

Production of acid from carbohydrates was examined by using $1 \%$ (w/v) carbohydrate in peptone water with $1 \%$ acid fuchsin in tubes.

Oxidase production was tested by pouring on colonies on nutrient agar a freshly prepared $1 \%(\mathrm{w} / \mathrm{v})$ solution of tetramethyl-p-phenylenediamine dihydrochloride containing $1 \%(\mathrm{w} / \mathrm{v})$ ascorbic acid to delay autoxidation of the reagent (Steel, 1962).

Estimation of urea was by the diacetyl method of Natelson, Scott \& Beffa (1951), but for the preliminary precipitation of protein the barium hydroxide and zinc sulphate method recommended by Dickenman, Crafts \& Zak (1954) was used.

Ultrasonic disruption of bacteria was done in a Dawe's Soniprobe (Dawe Instruments Ltd., Western Avenue, Acton, London, W. 3) with subsequent centrifugation and sterilization of the supernatant fluid through membrane filters (Oxoid brand; size $0 \cdot 5-1 \mu$ in diameter).

Estimations of cytoplasmic protein concentration were done by the Kjeldahl Nesslerization method (after Varley, 1960).

Test media for urease production. The following media were used: Rustigian \& Stuart (1941); Christensen (1946); the modification of the latter marketed by Messrs Oxoid Ltd ; the medium of Grelet (1946) modified by Lemoigne et al. (1952); Schneider \& Gunderson (1946); Elek (1946).

\section{RESULTS}

Detection of urease by cultural methods

For most of the substrates used, the instructions of the various originators were followed closely. In the case of the reagent used by Lemoigne et al. (1952), the authors simply stated that urea was used in Grelet's base; accordingly urea was added to this in an arbitrary concentration of $2 \%$. Incubation in all cases was for 1 week at $37^{\circ}$ except in the case of Elek's method where the tests were made after incubation for $3 \mathrm{hr}$ in a water bath at $37^{\circ}$.

The results are summarized in Table 3 .

Lemoigne et al. (1952), when using urea dissolved in Grelet's base, found that their strains of Neisseria winogradskyi (Acinetobacter anitratus) all yielded urease as revealed by ammonia production. However, the medium contains peptone and Henderson (1965) showed that all his strains produced ammonia from peptone, so the results obtained by the use of the medium that Lemoigne $e t$ al. used should be discounted. The varying results obtained from the use of the medium of Christensen (1946) and the Oxoid modification of it, and from the medium of Schneider \& Gunderson (1946), may have been due to a similar cause, since all contain peptone or tryptone. The medium of Rustigian \& Stuart (1941) supported growth badly; it is noteworthy that the two groups of workers who failed to find urease used this medium. 
The results obtained by use of the technique of Elek (1946) are acceptable if it can be shown that negative results are not due to utilization of the ammonia produced from the urea.

Table 3. Production of urease on various test media

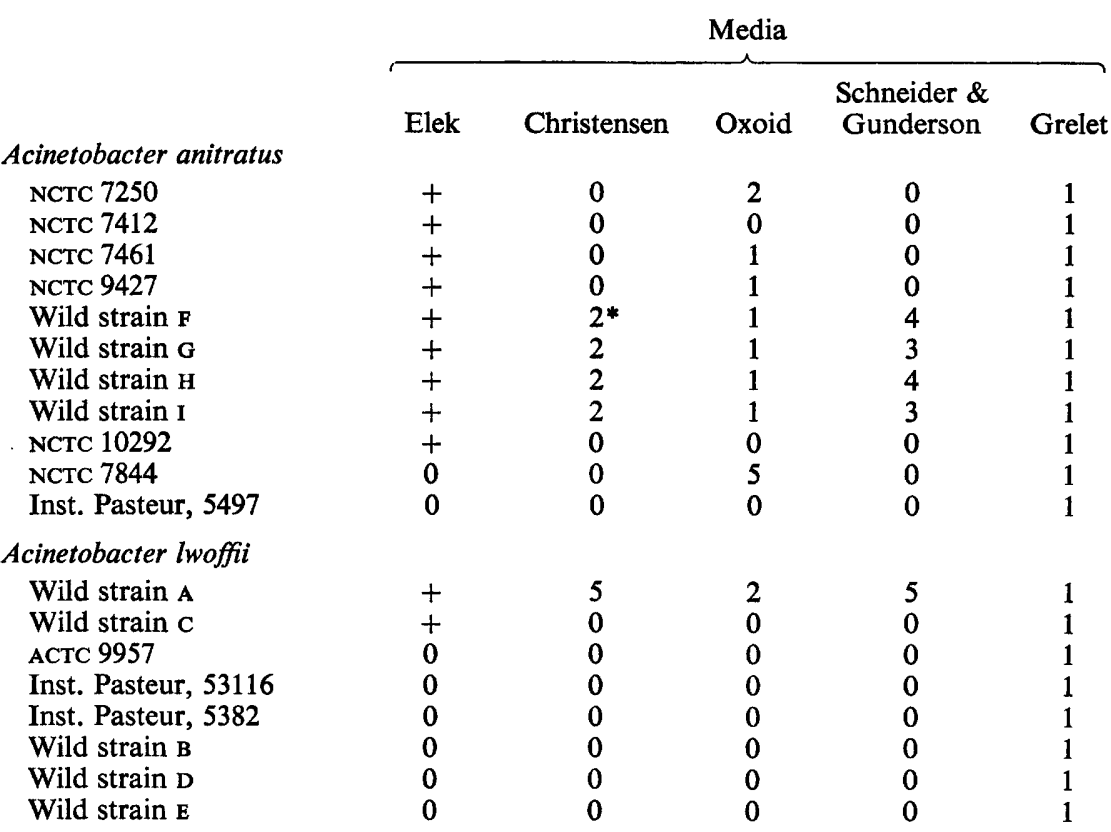

$+=$ Positive reaction. $0=$ Negative reaction. 1,2 , etc. $=$ no. of days incubation required for positive reaction.

\section{Detection of urease by estimation of bacterial consumption of urea}

When these bacteria grow in peptone water ammonia is produced. Accordingly, it was not possible to grow the bacteria in a solution of urea in peptone water and estimate residual urea after conversion to ammonia. The reagents available in such a contingency are: diacetyl monoxine (Barker, 1944), $\alpha$-isonitrosopropriophenone (Archibald et al. 1945); diacetyl (Natelson, Scott \& Beffa, 1951; Dickenman, Crafts \& Zak, 1954); acetylbenzoyl (Dickenman et al. 1954). It was decided to adopt a diacetyl method as utilized by Jeffries (1964).

Preliminary experiments showed that the method of Natelson et al. (1951) yielded results that were more linear between the limits 10 and $100 \mathrm{mg}$. urea $/ 100 \mathrm{ml}$. in the present investigator's hands than did the technique of Dickenman et al. (1954). Natelson et al. recommended reading the results in a spectrophotometer at $480 \mathrm{~m} \mu$, and it was found that peptone increased the extinction but did not affect the wavelength of maximal absorption. However, even trivial differences in boiling time due, for example, to varying numbers of tubes cooling the water in the bath caused large differences in the final extinction, with the result that graphs from different runs were dissimilar and a set of tubes for a full calibration curve had always to be included.

Bacteria were grown on nutrient agar, washed, and added to peptone water containing urea $100 \mathrm{mg} . / 100 \mathrm{ml}$., so that each $5 \mathrm{ml}$. sample of urea contained $0.005 \mathrm{~g}$. 
bacteria (wet weight). These urea solutions were incubated at $37^{\circ}$ and each day the bacteria were removed by centrifugation from one sample, chloroform added, and the supernatant fluid kept at $4^{\circ}$. At the end of 6 days the residual urea was estimated in each sample.

No graphs of the results are given since no convincing instance of urea consumption was noted. It was surprising that not one instance of a decrease in urea concentration was encountered. The author is indebted to Dr C. A. Fewson (Department of Biochemistry, University of Glasgow) for his suggestion that the presence of nitrogenous substances such as ammonia in the culture medium may suppress urease formation.

\section{Urea consumption by supernatant fuid of ultrasonically disrupted bacteria}

Preliminary tests indicated that optimal results were obtained after ultrasonic treatment for 10-15 min., followed by incubation with urea for 10 days. The bacteria were grown on nutrient agar, washed, and disrupted ultrasonically for $12 \mathrm{~min}$., the suspension centrifuged, the supernatant fluid sterilized by filtration through membrane filters and the protein estimated and diluted to $1 \mathrm{mg} . / \mathrm{ml}$. Samples of this filtrate were then added to an equal volume of an aqueous urea solution at $200 \mathrm{mg}$. and $1 \mathrm{mg} . / \mathrm{ml}$. respectively. Immediately on mixing, a small sample was withdrawn and stored at

Table 4. Urea consumption by membrane-sterilized filtrates of supernatant fluids after centrifugation of ultrasonically disrupted washed bacteria

$\begin{array}{lc}\quad \text { Organism } & \begin{array}{c}\text { Decrease in urea } \\ \text { concentration } \\ \text { (mg./ml.) }\end{array} \\ \text { Acinetobacter lwoffi } & \\ \text { ACTC 9957 } & 0 \\ \text { Inst. Pasteur, 53116 } & 0 \\ \text { Wild strain A } & 0 \\ \text { Wild strain C } & 0 \\ \text { A. anitratus } & \\ \text { NCTC 7844 } & 0 \\ \text { NCTC 7412 } & 0 \\ \text { NCTC 9427 } & 0 \\ \text { A. lwoffii } & \\ \text { Inst. Pasteur, 5382 } & 0-25 \\ \text { Wild strain B } & 0-25 \\ \text { Wild strain D } & 0-25 \\ \text { Wild strain E } & 0-25 \\ \text { A. anitratus } & \\ \text { NCrC 7461 } & 0-25 \\ \text { A. anitratus } & \\ \text { NCrC 7250 } & 24-50 \\ \text { NCTC 10292 } & 25-50 \\ \text { Wild strain F } & 25-50 \\ \text { Wild strain H } & 25-50 \\ \text { Wild strain I } & 25-50 \\ \text { A. anitratus } & \\ \text { Inst. Pasteur, 5497 } & 75-100 \\ \text { Wild strain G } & 75-100 \\ & \\ & \end{array}$


$-20^{\circ}$ to act as a control. The mixtures were then incubated at $37^{\circ}$ for 10 days, and the urea concentration remaining then estimated and compared with the controls.

The results are shown in Table 4.

The use of diacetyl as a reagent for the detection of urea was unsatisfactory in my hands as discussed above; very small variations in the boiling time caused large variations in the extinction; even the time required for the water to boil again after the cooling by immersion of the tubes caused great variation in the intensity of the colour produced. Similarly, the delay in transferring the tubes to the ice bath caused some tubes to have relatively longer heating. It was not found practicable to immerse large numbers of tubes in a thermostatically controlled, electrically heated bath, as the action of the paddle did not prevent unequal heating: the tubes nearer the heating element always attained a higher extinction value.

Table 5. Production of ammonia in g. per 100 g. urea by Acinetobacter lwoffii and A. anitratus

\begin{tabular}{|c|c|c|c|}
\hline Acinetobacter anitratus & $\begin{array}{l}\text { Ammonia } \\
\text { production } \\
\text { in g. from } \\
100 \mathrm{~g} \text {. urea }\end{array}$ & Acinetobacter lwoffii & $\begin{array}{l}\text { Ammonia } \\
\text { production } \\
\text { in g. from } \\
100 \text { g. urea }\end{array}$ \\
\hline NCTC 7250 & 0.5 & ACTC 9957 & $0 \cdot 8$ \\
\hline NCTC 7412 & 0.5 & Inst. Pasteur, 5382 & $1 \cdot 3$ \\
\hline NCTC 7461 & 0.5 & Inst. Pasteur, 53116 & $1 \cdot 5$ \\
\hline NCTC 7844 & 0.8 & Wild strain A & $1 \cdot 0$ \\
\hline NCTC 9427 & $1 \cdot 1$ & Wild strain B & $0 \cdot 8$ \\
\hline NCTC 10292 & $1 \cdot 3$ & Wild strain $\mathrm{C}$ & 0.8 \\
\hline Inst. Pasteur, 5497 & $1 \cdot 4$ & Wild strain D & 0.5 \\
\hline Wild strain $\mathbf{F}$ & $3 \cdot 2$ & Wild strain E & 0.5 \\
\hline Wild strain G & 1.9 & & \\
\hline Wild strain $\mathrm{H}$ & $2 \cdot 2$ & & \\
\hline Wild strain I & $3 \cdot 2$ & & \\
\hline
\end{tabular}

Because of these difficulties and because the urea concentration tended to decrease on incubation, it was decided to accept decreases in urea concentration of $0-25 \mathrm{mg}$./ $100 \mathrm{ml}$. as not significant, $25-50 \mathrm{mg} . / 100 \mathrm{ml}$. as slight urease production, and 50 $100 \mathrm{mg} . / 100 \mathrm{ml}$. as definite urease production.

All the strains of Acinetobacter lwoffi failed to produce urease, but 5 of 11 strains of $A$. anitratus gave similar negative results. Of the remaining strains of $A$. anitratus, 4 of 11 gave weak positive results and 2 of 11 definite positive results.

\section{Estimation of ammonia produced during growth in urea}

In each instance, one loopful of an overnight growth of the organism on nutrient agar was placed in $1.5 \mathrm{ml}$. of Elek urea medium. After incubation for $3 \mathrm{hr}$ in a water bath at $37^{\circ}$ the solutions were cleared by centrifugation, $0.5 \mathrm{ml}$. of each was withdrawn and added to $12 \mathrm{ml}$. distilled water; similarly $0.5 \mathrm{ml}$. of a solution of ammonium sulphate $(1 \mathrm{mg} . / \mathrm{ml}$.) was added to $12 \mathrm{ml}$. distilled water. From each of the urea solutions $2 \mathrm{ml}$. was withdrawn and added to $5 \mathrm{ml}$. water and $3 \mathrm{ml}$. Nessler reagent; from the ammonium solution $1 \mathrm{ml}$. was taken and added to $6 \mathrm{ml}$. water and $3 \mathrm{ml}$. Nessler reagent; then the ammonia concentrations were estimated in a photoelectric colorimeter. 
The results are given in Table 5. It is seen that every organism produced ammonia from urea. The quantities are not comparable since the inocula were unequal.

Forty more strains were examined by Elek's method ( 20 from human sources, 20 freshly isolated from soil). These results are shown in Table 6.

Table 6. Production of urease by 40 additional strains

\begin{tabular}{lccc} 
Source & $\begin{array}{c}\text { Urease } \\
\text { activity }\end{array}$ & \multicolumn{2}{c}{$\begin{array}{c}\text { Saccharolytic } \\
\text { activity }\end{array}$} \\
Human & $19+$ & $17+$ & $2-$ \\
& $1-$ & $0+$ & $1-$ \\
Earth & $18+$ & $12+$ & $6-$ \\
& $2-$ & $1+$ & $1-$
\end{tabular}

\section{DISCUSSION}

All of the strains of bacteria examined, no matter whether regarded as Acinetobacter lwoffi or A. anitratus, produced urease when no peptone was present and when incubation was brief. Thus no distinction can be made between these two organisms on this basis. Confusion in the past appears to have arisen from three sources: the liberation of ammonia from peptone in the basal media; no allowance being made for the possibility that an organism might resynthesize urea from other nitrogenous precursors; the role of ammonia in suppressing urease formation. König, Kaltwasser \& Schlegel (1966) have demonstrated similar suppression of urease formation by ammonia in a Hydrogenomonas strain.

The author wishes to thank Dr C. A. Fewson for suggestions during this work; Dr H. Girard (Institut Pasteur, Paris) for the strain of Neisseria winogradskyi (Acinetobacter anitratus); Dr A. D. T. Govan for the facilities made available in his laboratory; and Professor E. O. Morris for the use of his soniprobe.

\section{REFERENCES}

Archibald, R. M., Ortiz, P., Struh, E. \& Branner, J. (1945). Colorimetric determination of urea. J. biol. Chem. 157, 507.

BARKer, S. B. (1944). The direct colorimetric determination of urea in blood and urine. J. biol. Chem. 152, 453.

Barrit, M. M. (1936). The intensification of the Voges-Proskauer reaction by the addition of alphanaphthol. J. Path. Bact. 42, 441.

BRoOKE, M. S. (1951). The occurrence of в $5 \mathrm{w}$ (B. anitratum) strains in Denmark. Acta path. microbiol. scand. $28,338$.

Christensen, W. B. (1946). Urea decomposition as a means of differentiating Proteus and Paracolon cultures from each other and from Salmonella and Shigella types. J. Bact. 52, 461.

Cowan, S. T. \& Steel, K. J. (1965). Manual for the Identification of Medical Bacteria. Cambridge University Press.

Dickenman, R. C., Crafts, B. \& ZAK, B. (1954). Use of alpha diketones for analysis of urea. $A m$. J. clin. Path. 24, 981.

EleK, S. D. (1946). Rapid identification of Proteus. J. Path. Bact. 60, 183.

FERGUSON, W. W. \& RoBerTs, L. F. (1950). A bacteriological and serological study of organism B $5 \mathrm{~W}$ (Bacterium anitratum). J. Bact. 59, 171.

Grelet, N. (1946). Culture du Bacillus megatherium en milieu synthétique glucosé. Ann. Inst. Pasteur, $72,153$.

Henderson, A. (1965). The Moraxella lwoffii group of bacteria, a review. Antonie van Leeuwenhoek 31, 395. 
JefrRIES, C. D. (1964). Urease activity of intact and disrupted bacteria. Arch. Path. 77, 544.

JYSSUM, K. \& JONER, P. E. (1965a). Growth of Bacterium anitratum (B $5 \mathrm{w})$ with nitrate or nitrite as nitrogen source. Acta path. microbiol. scand. 64, 381.

JYSSUM, K. \& JoNER, P. E. (1965 $b$ ). Regulation of the nitrogen assimilation from nitrate and nitrite in Bacterium anitratum. Acta path. microbiol. scand. 64, 387.

König, C., Kaltwasser, H. \& SChlegel, H. G. (1966). Die Bildung von Urease nach Verbrauch der äusseren N-Quelle bei Hydrogenomonas H-16. Archiv Mikrobiol. 53, 231.

Lemoigne, M., Girard, H. \& JaCOBelli, G. (1952). Bactérie du sol utilisant facilement le 2-3butandiol. Ann. Inst. Pasteur 82, 389.

MINISTRY OF HEALTH (1934). Reports on public health and medical subjects. No. 71, 32. London: H.M.S.O.

NATELSON, S., ScotT, M. L. \& BefFa, C. (1951). A rapid method for the estimation of urea in biologic fluids. Am. J. clin. Path. 21, 275.

Rustigian, R. \& Stuart, C. A. (1941). Decomposition of urea by Proteus. Proc. Soc. exp. Biol. Med. 47, 108.

SChAUB, I. G. \& HAUBER, F. D. (1948). A biochemical and serological study of a group of identical unidentifiable gram-negative bacilli from human sources. J. Bact. 56, 379.

SCHNeIder, M. D. \& Gunderson, M. F. (1946). A new medium for the detection of urea-splitting organisms. J. Bact. 52, 303.

SteEL, K. J. (1962). The oxidase activity of staphylococci. J. appl. Bact. 25, 445.

Stuart, C. A., Formal, S. \& McGanN, V. (1949). Further studies on B 5 w, an anaerogenic group in the Enterobacteriaceae. J. infect. Dis. 84, 235.

VARLEY, H. (1960). Determination of protein by Kjeldahl Nesslerisation method. In Practical Clinical Biochemistry, p. 183. London: Wm. Heinemann Medical Books Ltd. 